\title{
A Brief Introduction to Natural Fibers and Preparation of Lignocelluloses for Different Applications
}

\author{
Qaisar Abbas ${ }^{1 *}$, Qaiser Atta ${ }^{1}$, Aqsa Hashmi1 ${ }^{1}$, Muhammad Rafiq ${ }^{2}$, Faisal Munir ${ }^{3}$, Aroosah Tabassum ${ }^{4}$ \\ ${ }^{1}$ Department of Physics, COMSATS University Islamabad, Pakistan
}

${ }^{2}$ QAED Kot Addu, Pakistan

${ }^{3}$ Department of Computer Science, IIU Islamabad, Pakistan

${ }^{4}$ Department of Environmental sciences, Bahauddin Zakariya University, Multan

Submission: July 19, 2019; Published: September 18, 2019

*Corresponding author: Qaisar Abbas, Department of Physics, COMSATS University Islamabad, Lahore Campus 54000, Pakistan

\begin{abstract}
In this research we discussed the brief introduction of natural fibers and different plants were collected and by chemical method lignocelluloses sheet was fabricated which further can be used for many different applications such as in textile industry also it can be used with nanomaterials for flexible energy devices. Lignocellulosic fibers were attained by mechanical separation from monochoria vaginalis and Typha Angustifolia plants, and then after drying of fibers, fibers sheet fabricated by bleaching of fiber with different concentration, the lignocellulose fiber sheets were so flexible that can twist into any geometrical shape and can cut with the help of scissor. That can help to prepare many flexible devices such as wearable energy devices.
\end{abstract}

\section{Introduction}

"Fibers are the hair like materials, like the piece of thread. There are two kinds of fibers: Natural Fibers, which consists of plant and Self-made fibers: which consists of synthetic fibers and regenerated fibers $[1,2]$. Plant fibers are light weight, flexible and having good mechanical properties [3]. Hence natural fibers are very useful in many applications. The type of fibers depends upon the sources. It has been noted that fibers having different origin had different mechanical, rigidity, flexibility and biodegradable properties [4-6]. The length of natural fiber is approximately $1 \mu \mathrm{m}-50 \mu \mathrm{m}$ and diameter of the fiber is the order of $10 \mathrm{~nm}-50 \mathrm{~nm}$ nanofibers exist in cell wall $[7,8]$. The natural fibers are made up of many cell walls. If we remove these cell walls one by one, we will see that it contains nano cellulose fibers in it. These nano fibers add up the strength of the fiber. The main part of natural fiber or plant fibers is cellulose wrapped around nano and micro cellulose which are stick together by lignin which totally made up lignocellulose" [9]. The pulp and paper industry processes large quantities of lignocelluloses biomass in every year [10-22]. Historically, plants have found some uses in pulp and paper industry, but these fibers have been confined to areas such as modifications of raw starch fibers [23-35]. Over the years, the number of possible applications of plant fibers in pulp and paper industry has increased steadily [36-39]. The pulp and paper industry processes large quantities of lignocelluloses biomass in every year. Historically, plants have found some uses in pulp and paper industry, but these fibers have been confined to areas such as modifications of raw starch fibers [35].

Over the years, the number of possible applications of plant fibers in pulp and paper industry has increased steadily [36-39]. Lignocellulose are widely being used in in pulp and paper industries $[40,41]$. Lignocelluloses biomass in the form of plant fuel, has a very long history as a source of energy [42]. Industrial biomass composed on lignocelluloses waste, which is renewable, inexpensive, abundant and provides a natural resource for large-scale and cost-effective bio-energy collection [43-45]. Lignocellulose also have application in Biofuels and Bioethanol [46-48] Vehicle industry around the world used the lignocellulose fiber-based composites parts in the vehicles e.g. foot mats interior, rugs etc. [49-51]. Many applications have been reported for use of Lignocellulose application in automobiles [52]. Now a day's natural/nano lignocellulose fiber composites are using in the construction of the buildings [53,54]. A large 
quantity of lignocelluloses plant wastes is generated worldwide from different sources leading to environmental issues. By use of these lignocelluloses wastes in making cement-bonded construction materials, we can reduce the magnitude of different problems [55-57]. Lignocellulose fibers are used as a composite form to be mixed with rubber, fibers provide good strength to them [25,53,58-62]. It adds up strength and stiffness when mix with other materials [9,63-67]. Lignocellulose fibers are also used to avoid erosion of soil and for the protection of the seeds [68]. Lignocellulose fibers are also used to avoid erosion of soil and for the protection of the seeds" [68].

Lignocellulose application in soil conservation materials are also reported $[68,69]$."Bacterial lignocellulose fiber has found many applications in the biomedical field as tissue engineering materials due to their good biocompatibility, mechanical properties similar to those of hard and soft tissue and easy fabrication into a variety of shapes with adjustable interconnected porosity [70-72]. Lignocellulose Paper-based supercapacitors, a very interesting and novel group of flexible and environmentally friendly energy storage devices, are attracting a great attention from the industry. Lignocellulose fibers with a unique porous bulk structure and absorptive surface properties enable the paper-based energy storage devices with a reasonably good conductivity performance at a very low cost" [73].

\section{Experimental}

\section{Collection of Typha Angustifolia}

For the collection of Typha Angustifolia southern Punjab Pakistan District Muzaffargarh village was selected and as these are self-growing plants so was easily available in steady water (Figure 1).

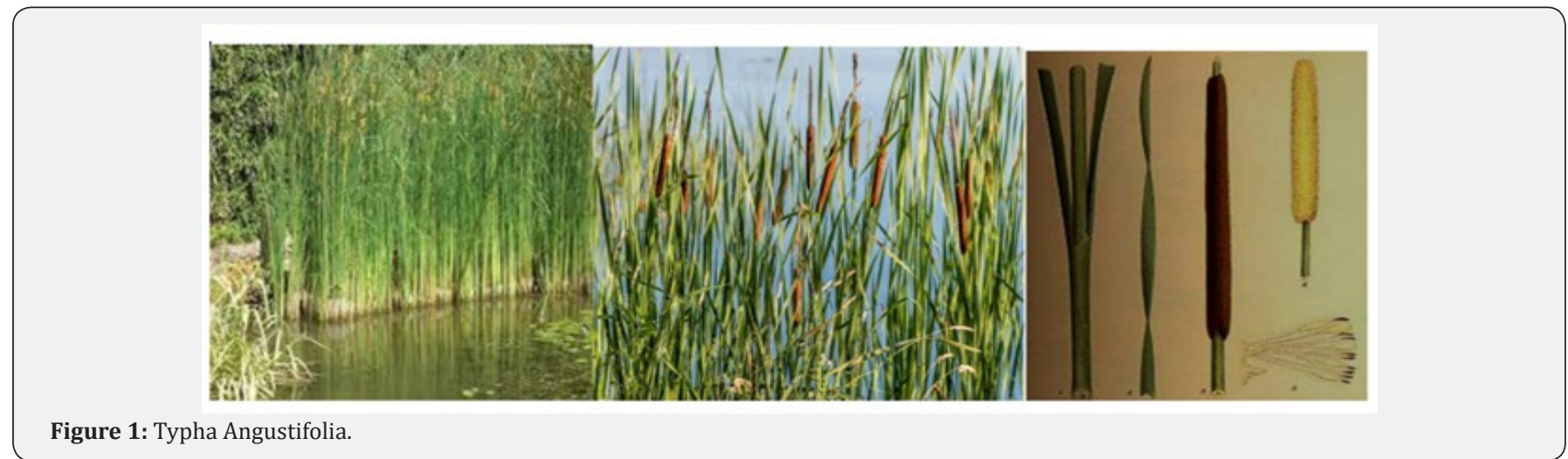

\section{Material and Preparation Method}

"In this regard the first plant Typha Angustifolia (cat-tail) was chosen as plant source for the preparation and analysis of lignocellulose nanofibers. Typha Angustifolia (cat-tail) was collected Southern Punjab District Muzaffargarh Pakistan. Only leaves cut into lengths were used. The outer skin of the bark was peeled from the leaves by hand and used for fiber extraction. Samples were air-dried and stored at room temperature. The second plant which we selected for our research work was monochoria vaginalis (water hyacinth) commonly known as singhara in native Lahore. The reason behind this selection was that it is a self-grown plant. There is no need to plant it and to spend money and our energy on it. It is easily available and grow in any water populated area for example a pound most of contaminated water. We select this plant for our research work because monochoria vaginalis (MV) is softer for sheet preparation than the first plant" (Figure 2). Then extract the fibers from its stems with scissor. The fibers are in wet form. Then these fibers were dried for 3 days for further processes (Figure 3).
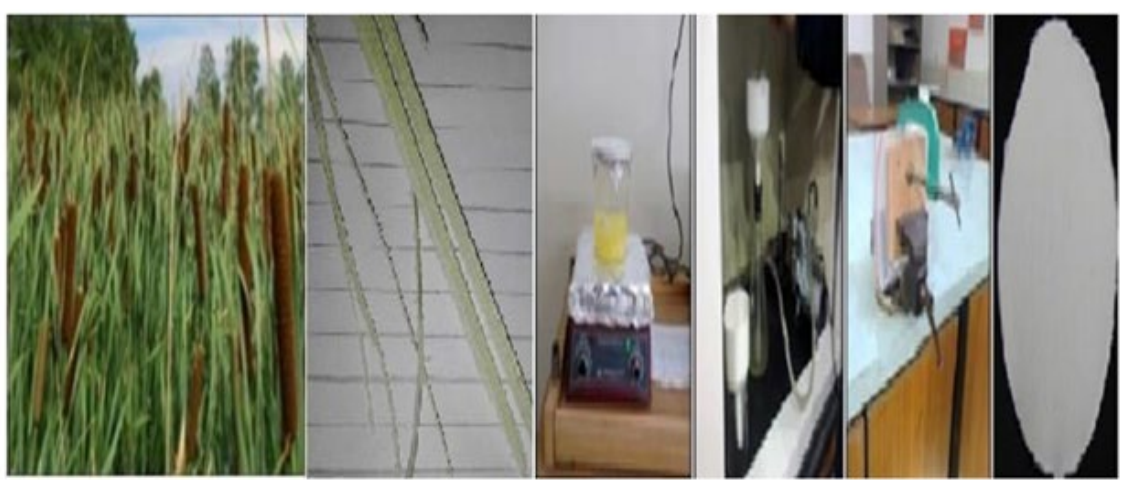

Figure 2: Prepared LC sheet and Fibers. 


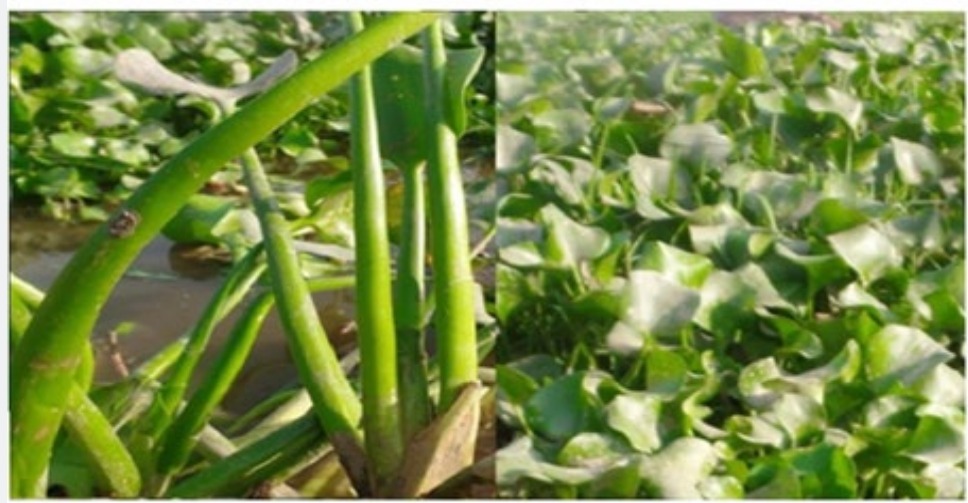

Figure 3: Monochoriavaginalis.

\section{Preparation of Lignocelluloses Sheet}

"1.0 g of Raw Monochoria Vaginalis (MV)lignocellulose fibers were cut into small pieces. Fibers were first dispersed in $40 \% \mathrm{NaOCl}$ solution $(150 \mathrm{~mL})$. Then bleached fibers were treated at room temperature for 2 hours under constant stirring (500rpm). After that, we grind the solution in mortar and pestle for 30minutes (Figure 4). We again do the stirring process for 30 minutes. Again, grind the solution for 20 minutes in mortar and pestle. Now the slurry solution was filtered on filter paper (90mm-d) in a Buchner funnel connected to a suction flask and vacuum as shown in diagram" (Figure 5).

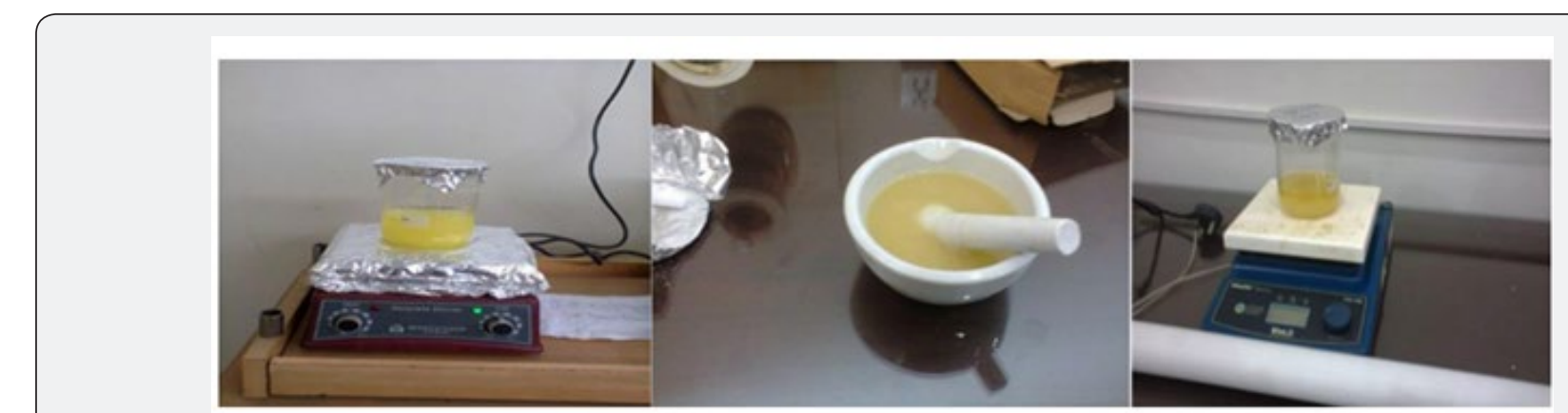

Figure 4: Preparation of lignocellulose sheet.

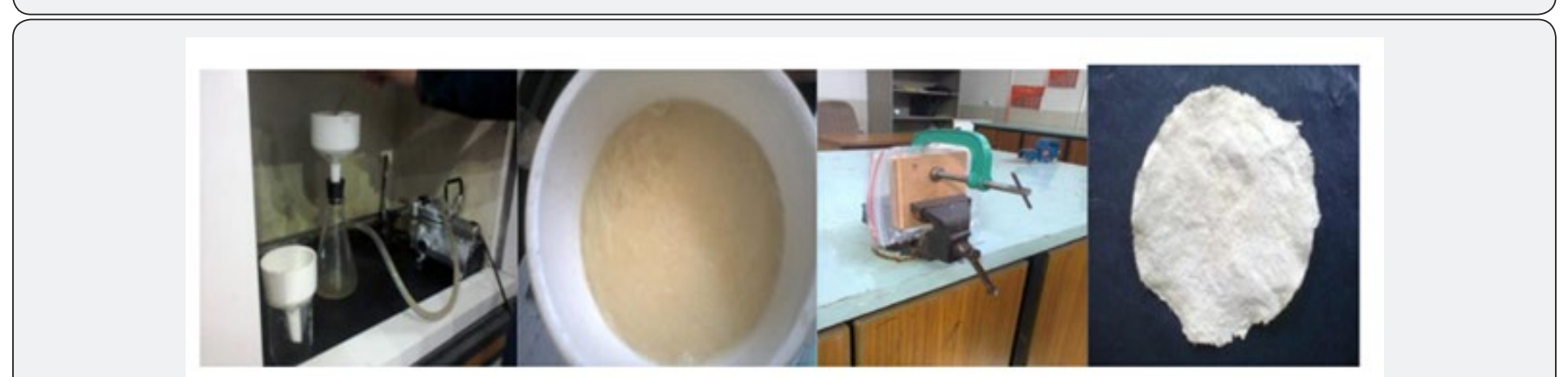

Figure 5: Preparation of lignocellulose sheet.

\section{Conclusion}

The lignocelluloses are extracted from natural occurring plants which is most important for the cost factor. It can be used in different applications at lowest cost. The extracted fibers can be used in energy sectors, textile, and paper industry etc. Moreover, the preparation method is also easy, and no special labs are required via simple chemical process lignocelluloses can be prepared having less investment on preparation, so these are interesting fibers for further research.

\section{References}

1. Balter M (2009) Clothes Make the (Hu) Man. Science 325(5946): 13291337.

2. Kvavadze E, Ofer Bar-Yosef, Anna Belfer-Cohen, Elisabetta Boaretto, Nino Jakeli, et al. (2009) 30,000-Year-Old Wild Flax Fibers. Science 325(5946): 1359-1366.

3. Morton WE, Hearle JWS (1993) Physical properties of textile fibres. London: The Textile Institute.

4. Bledzki AK, Gassan J (1999) Composites reinforced with cellulose based fibres. Progress in Polymer Science 24(2): 221-274. 
5. Pedro JHF, et al. (2005) Fiber-Matrix Adhesion in Natural Fiber Composites, in Natural Fibers, Biopolymers, and Biocomposites. CRC Press.

6. Kraessig H (1987) Cellulose chemistry and its applications. Journal of Polymer Science Part C: Polymer Letters 25: 87-88.

7. Tsoumis GT (1991) Science and technology of wood : structure, properties, utilization. Van Nostrand Reinhold: New York 1-11.

8. Rojas J, Mauricio Bedoya, Yhors Ciro (2015) Current Trends in the Production of Cellulose Nanoparticles and Nanocomposites for Biomedical Applications. Cellulose 13: 457-464.

9. Yao F, Qinglin Lei, Yong Xu, Yanjun (2008) Rice straw fiber-reinforced high-density polyethylene composite: Effect of fiber type and loading. Industrial Crops and Products 28(1): 63-72.

10. Rodrigues PC, Alvaro Mathias, Luiz Ramos, Paulo Roberto Janissek, Paulo Cesar Almei, et al. (2002) Polyaniline/lignin blends: FTIR, MEV and electrochemical characterization. European Polymer Journal 38(11): 2213-2217.

11. Adams GA, Bishop CT (1953) Polysaccharides associated with AlphaCellulose. Nature 172: 28-29.

12. Ritter GJ (1929) Determination of alpha- cellulose. Industrial \& Engineering Chemistry Analytical Edition 1(1): 52-54.

13. Licea-Jiménez L, Henrio P-Y, Lund A, Laurie TM, Pérez-García SA (2007) MWNT reinforced melamine-formaldehyde containing alpha-cellulose. Composites Science and Technology 67(5): 844-854.

14. Maiolini R, Rene F Masseyeff (1975) A sandwich method of enzymoimmunoassay. I. Application to rat and human alphafetoprotein. Journal of Immunological Methods. 8(3): 223-234.

15. Powers DH, Moorestown NJ, Louis H Bock, Alva L Houk, Philadelphia (1940) Water soluble ethers of alpha cellulose. Google Patents.

16. Saikia CN, Ali F, Goswami T, Anil C Ghosh (1995) Esterification of high $\alpha$-cellulose extracted from Hibiscus cannabinus L. Industrial Crops and Products 4(4): 233-239.

17. Van Soest PJ (1967) Development of a Comprehensive System of Feed Analyses and its Application to Forages. Journal of Animal Science 26: 119-128.

18. Launer HF (1974) Simplified volumetric determination of alpha, beta, and gamma cellulose in pulps and papers. US Government Printing Office 18: 333-342.

19. Jackson EL, Hudson CS (1937) Application of the Cleavage Type of Oxidation by Periodic Acid to Starch and Cellulose. Journal of the American Chemical Society 59(10): 2049-2050.

20. Gehmayr V, Gabriele Schild, Herbert Sixta (2011) A precise study on the feasibility of enzyme treatments of a kraft pulp for viscose application. Cellulose 18(2): 479-491.

21. Sternberg D (1976) Beta-glucosidase of Trichoderma: its biosynthesis and role in saccharification of cellulose. Applied and environmenta microbiology 31(5): 648-654.

22. Bray MW, Andrews TM (1923) An Improved Method for the Determination of Alpha-, Beta-, and Gamma-Cellulose. Industrial \& Engineering Chemistry 15(4): 377-378.

23. Tasaki I, Kyuei Kibe (1959) A study on the digestion of cellulose in poultry. Poultry Science 38(2): 376-379.

24. Bledzki AK, Abdullah A Mamun, Adam Jaszkiewicz, Karsten Erdmann (2010) Polypropylene composites with enzyme modified abaca fibre. Composites Science and Technology 70(5): 854-860.

25. Sangthong S, Thirawudh Pongprayoon, NantayaYanumet (2009) Mechanical property improvement of unsaturated polyester composite reinforced with admicellar-treated sisal fibers. Composites Part A: Applied Science and Manufacturing 40(6-7): 687-694.
26. Wang ZF, Zheng Peng, Si-Dong Li, Hua Lin, Ke-Xi Zhang, et al. (2009) The impact of esterification on the properties of starch/natural rubber composite. Composites Science and Technology 69(11-12): 1797-1803.

27. Towo AN, Martin P Ansell (2008). Fatigue of sisal fibre reinforced composites: Constant-life diagrams and hysteresis loop capture. Composites Science and Technology 68(3-4): 915-924.

28. Huang X, Anil Netravali (2009) Biodegradable green composites made using bamboo micro/nano-fibrils and chemically modified soy protein resin. Composites Science and Technology 69(7-8): 1009-1015.

29. Lee BH, Hee-Soo Kim, Sena Lee, Hyun-Joong Kim, John R Dorgan (2009) Bio-composites of kenaf fibers in polylactide: Role of improved interfacial adhesion in the carding process. Composites Science and Technology 69(15-16): 2573-2579.

30. Willats WG, MC Cartney L, Mackie W, Knox JP (2001) Pectin: cell biology and prospects for functional analysis. 47(1-2): 9-27.

31. Kay RM, Truswell AS (1977) Effect of citrus pectin on blood lipids and fecal steroid excretion in man. The American journal of clinical nutrition 30(2): 171-175

32. Wood PJ, Siddiqui IR (1971) Determination of methanol and its application to measurement of pectin ester content and pectin methyl esterase activity. Analytical biochemistry 39(2): 418-428.

33. Jenkins DJ, Leeds AR, Gassull MA, Cochet B, Alberti GM (1977) Decrease in postprandial insulin and glucose concentrations by guar and pectin. Annals of internal Medicine 86(1): 20-23.

34. Bajpai P (1999) Application of enzymes in the pulp and paper industry. Biotechnology progress 15(2): 147-157.

35. Beg Q, Kapoor M, Mahajan L, Hoondal GS (2001) Microbial xylanases and their industrial applications: a review. Applied microbiology and biotechnology 56(3-4): 326-338.

36. Wong KK (1993) Applications of hemicellulases in the food, feed, and pulp and paper industries. Hemicellulose and hemicellulases 4: 127143.

37. Reddy N, Yiqi Yang (2005) Biofibers from agricultural byproducts for industrial applications. TRENDS in Biotechnology 23(1): 22-27.

38. Kirk O, Borchert TV, Fuglsang CC (2002) Industrial enzyme applications. Current opinion in biotechnology 13(4): 345-351.

39. Thompson G, Swain J, Kay M, Forster CF (2001) The treatment of pulp and paper mill effluent: a review. Bioresource technology 77(3): 275286.

40. Casey JP (1952) Pulp and paper. Chemistry and chemical technology 64(19-20): 521-576.

41. Carroll A, Chris Somerville (2009) Cellulosic Biofuels. Annual Review of Plant Biology 60: 165-182.

42. Anwar Z, Muhammad Gulfraz, Muhammad Irshad (2014) Agroindustrial lignocellulosic biomass a key to unlock the future bioenergy: A brief review. Journal of Radiation Research and Applied Sciences 7(2): 163-173.

43. Stöcker M (2008) Biofuels and biomass-to-liquid fuels in the biorefinery: Catalytic conversion of lignocellulosic biomass using porous materials. Angewandte Chemie International Edition 47(48): 9200-9211.

44. Menon V, Mala Rao (2012) Trends in bioconversion of lignocellulose: biofuels, platform chemicals \& biorefinery concept. Progress in Energy and Combustion Science 38(4): 522-550.

45. Zhao YL, Dolat A, Steinberger Y, Wang Xin, Osman A, et al. (2009) Biomass yield and changes in chemical composition of sweet sorghum cultivars grown for biofuel. Field Crops Research 111(1/2): 55-64. 
46. Chisti Y (2007) Biodiesel from microalgae. Biotechnology advances 25(3): 294-306.

47. Ma F, Milford A Hanna (1999) Biodiesel production: a review. Bioresource technology 70: 1-15.

48. Zhu H, Shen Jinyu, Zhang Huapeng, Feng Xinxing, Guo Yuhai, et al. (2010) Fabrication and characterization of bioactive silk fibroin/ wollastonite composite scaffolds. Materials Science and Engineering: C 30(1): 132-140.

49. Hill S (1997) Cars that grow on trees. New Sci 2067: 36-39.

50. Suddell BC, WJ Evans (2005) Natural fiber composites in automotive applications. Natural fibres, biopolymers and biocomposites 37: 45-57.

51. Satyanarayana K, JL Guimarães, F Wypych (2007) Studies on lignocellulosic fibers of Brazil. Part I: Source, production, morphology, properties and applications. Composites Part A: Applied Science and Manufacturing 38(7): 1694-1709.

52. Mohanty AK, Manjusri Misra, Lawrence T Drzal (2005) Natural fibers, biopolymers, and biocomposites. CRC Press pp: 896.

53. Singh B, Gupta M (2005) Natural fiber composites for building applications. Natural fibres, biopolymers and biocomposites 197: 231246

54. Pacheco-Torgal F, Said Jalali (2011) Cementitious building materials reinforced with vegetable fibres: A review. Construction and Building Materials 25: 575-581.

55. Karade S (2010) Cement-bonded composites from lignocellulosic wastes. Construction and building materials 24(8): 1323-1330.

56. Bergquist BL, Mohammed F Fahmy (1993) Structural materials from recycled high density polyethylene and herbaceous fibers, and method for production. p. 1-8.

57. Van Smith T, Dallas (1977) Construction material of recycled waste thermoplastic synthetic resin and cellulose fibers.

58. Bax B, Jörg Müssig (2008) Impact and tensile properties of PLA/ Cordenka and PLA/flax composites. Composites Science and Technology 68(7-8): 1601-1607.

59. Beckermann G, Pickering KL (2008) Engineering and evaluation of hemp fibre reinforced polypropylene composites: fibre treatment and matrix modification. Composites Part A: Applied Science and Manufacturing 39(6): 979-988.

60. Sangthong S, Thirawudh Pongprayoon, Nantaya Yanumet (2009) Mechanical property improvement of unsaturated polyester composite reinforced with admicellar-treated sisal fibers. Composites Part A: Applied Science and Manufacturing 40(6-7): 687-694.

61. Towo AN, Martin P Ansell (2008) Fatigue of sisal fibre reinforced composites: Constant-life diagrams and hysteresis loop capture. Composites Science and Technology 68(3-4): 915-924.

62. Kritschewsky G (1985) Chemical technology of textile materials.

63. Huang X, Anil N (2009) Biodegradable green composites made using bamboo micro/nano-fibrils and chemically modified soy protein resin. Composites Science and Technology 69(7-8): 1009-1015.

64. Lee BH, Hee SK, Sena L, Hyun JK, John RD, et al. (2009) Bio-composites of kenaf fibers in polylactide: Role of improved interfacial adhesion in the carding process. Composites Science and Technology 69(15-16): 2573-2579.

65. Shih YF, Wei C, Chung H (2010) Biodegradable green composites reinforced by the fiber recycling from disposable chopsticks. Materials Science and Engineering 527(6): 1516-1521.

66. Suryanegara L, Antonio Norio Nakagaito, Hiroyuki Yano (2009] The effect of crystallization of PLA on the thermal and mechanical properties of microfibrillated cellulose-reinforced PLA composites. Composites Science and Technology 69(7-8): 1187-1192.

67. Malherbe S, Cloete TE (2002) Lignocellulose biodegradation: Fundamentals and applications. Reviews in Environmental Science and Biotechnology 1(2): 105-114.

68. McConnell KE (1983) An economic model of soil conservation American journal of agricultural economics 65(1): 83-89.

69. Kamel S (2007) Nanotechnology and its applications in lignocellulosic composites, a mini review. Express Polymer Letters 1(9): 546-575.

70. Edwards JV, Vincent, Buschle-Diller, Gisela, Goheen, et al. (2006) Modified fibers with medical and specialty applications.

71. Rials TG, Michael P Wolcott, John M Nassar (2001) Interfacial contributions in lignocellulosic fiber-reinforced polyurethane composites. Journal of Applied Polymer Science 80: 546-555.

72. Kozlowski R (2000) Green fibres and their potential in diversified applications. in Proceedings of a Seminar held by the Food and Agriculture Organization of the UN (FAO) and the Common Fund for Commodities (CFC)

73. Yi-Zhou Zhang, Yang Wang, Tao Cheng, Wen-Yong Lai, Huan Pang, et al. (2015) Flexible supercapacitors based on paper substrates: a new paradigm for low-cost energy storage. Chemical Society Reviews 44(15): 5181-5199.
Your next submission with Juniper Publishers will reach you the below assets

- Quality Editorial service

- Swift Peer Review

- Reprints availability

- E-prints Service

- Manuscript Podcast for convenient understanding

- Global attainment for your research

- Manuscript accessibility in different formats

( Pdf, E-pub, Full Text, Audio)

- Unceasing customer service

Track the below URL for one-step submission https://juniperpublishers.com/online-submission.php 